\title{
Asymmetric dimethylarginine, the promoter factor of cardiovascular pathologies
}

\author{
Dimetilarginina asimetrică, factorul promotor al afecțiunilor \\ cardiovasculare
}

\author{
Anamaria VÎLCEA ${ }^{1}$, Maria PUŞCHIȚĂ² \\ ${ }^{1}$ Spitalul Clinic Județean de Urgență, Arad, România \\ ${ }^{2}$ Facultatea de Medicină, Universitatea de Vest „Vasile Goldiș“, Arad, România
}

\begin{abstract}
Amongst all the cardiovascular risk factors known until now, it has been recently discovered one that acts independently and has powerful proatherogenic properties. Its action leads to a quick endothelium damage through increased oxidative stress at this level. Asymmetric dimethylarginine, a metilated protein, is a new prognostic factor of cardiovascular pathologies and its importance started to appear lately, when studies performed on patients with renal failure contoured an increased mortality due to cardiovascular complications in these patients. The particular characteristic that makes it different than the other known risk factors is its capacity to directly compete against nitric oxide synthase, being the most powerful inhibitor, leading to a proatherogenic state.
\end{abstract}

Keywords: asymmetric dimethylarginine, endothelium dysfunction, cardiovascular risk factors, hypercholestrolaemia

\section{REZUMAT}

Dintre toți factorii de risc cunoscuți până în prezent, recent, a fost descoperit unul care acționează independent, având proprietăți proaterogenice puternice. Acțiunea sa conduce la o disfuncție endotelială prin stres oxidativ crescut la acest nivel. Dimetilarginina asimetrică, o proteină metilată, este un nou factor de prognostic negativ al afecțiunilor cardiovasculare, iar importanța acesteia a început să apară în ultimii ani, când studiile efectuate pe pacienții cu insuficiență renală au conturat o mortalitate crescută din cauza complicațiilor cardiovasculare apărute la aceşti pacienți.

Caracteristica particulară ce diferențiază acest factor de risc de ceilalți cunoscuți până în prezent este capacitatea dimetilargininei asimetrice de a concura direct cu sintaza oxidului nitric, fiind cel mai puternic inhibitor al acestuia, favorizând aterogeneza.

Cuvinte cheie: dimetilarginină asimetrică, disfuncție endotelială, factori de risc cardiovasculari, hipercolesterolemie

\section{Abrevieri:}

DMAA - dimetilarginina asimetrică

PRMT - protein-arginin metiltransferază
DDAH I - dimetilarginin dimetilaminohidrolaza I

$\mathrm{NO}$ - oxid nitric 


\section{INTRODUCERE}

Afecțiunile cardiovasculare reprezintă în momentul de față prima cauză de deces în rândul populației. La începutul secolului 20, bolile cardiovasculare au fost răspunzătoare pentru mai puțin de $10 \%$ din decesele înregistrate în aceea perioadă, dar, până în prezent, riscul cardiovascular s-a triplat, ajungând undeva la 30\%. De-a lungul timpului, cele mai frecvente decese raportate de cauză cardiovasculară s-au declarat în țările mai slab dezvoltate, dar, treptat, incidența lor a început să crească și în țările bine dezvoltate. În principiu, substratul afecțiunilor cardiovasculare are numeroși factori de risc comuni. Dintre cauzele cu cea mai mare mortalitate cardiovasculară amintim insuficiența cardiacă, infarctul miocardic și hipertensiunea arterială. Mulți pacienți hipertensivi bagatelizează boala cardiovasculară pe care o au, care însă, netratată, poate duce la infarct miocardic și insuficiență cardiacă. Se observă conexiunea strânsă dintre cele trei patologii, una potențând-o pe cealaltă. Riscul de a dezvolta insuficiență cardiacă este de două ori mai mare la bărbații hipertensivi și de trei ori mai mare la femeile hipertensive față de cele normotensive (1). Riscul de a dezvolta o patologie cardiovasculară este potențat în mare parte de prezența mai multor factori de risc: consumul de tutun, tensiunea arterială crescută, valorile glicemice mari, dislipidemia, obezitatea și sedentarismul. O mare parte dintre stimulii patologici descriși potențează stresul oxidativ la nivel endotelial. Factorii de risc cardiovasculari, atât cei influențabili, cât și cei neinfluențabili cunoscuți până în prezent, acționează de obicei sinergic. În ultimii ani, un nou factor de risc, dimetilarginina asimetrică (DMAA), a amprentat puternic prognosticul pacienților cu afecțiuni cardiovasculare, acționând independent ca unul dintre cei mai puternici inhibitori competitivi endogeni ai oxidului nitric, fiind un rest proteic provenit din metilarea posttranslațională a resturilor de L-arginină.

\section{PRIMA DESCOPERIRE A DIMETILARGININEI ASIMETRICE}

În anul 1970, primii cercetători care au descoperit dimetilarginina asimetrică din urina umană au fost doi japonezi, Kakimoto şi Akazawa, dar doar în ultimii ani s-a pus accent mai mare pe implicația acestora în diverse patologii. Concentrația plasmatică a acestei metilproteine a fost urmărită într-o gamă largă de afecțiuni cu substrat cardiovascular (2). În urma primelor studii efectuate de la descoperirea acestora, s-a creionat faptul că metilargininele sunt excretate în urină, demonstrându-se astfel implicația dimetilargininei asimetrice în antagonizarea vasodilatației dependente de endoteliu la pacienții cu insuficiență renală cronică aflată în stadiul terminal (3). Din momentul în care este afectată funcția renală, concentrația plasmatică de DMAA creşte treptat. Este, de asemenea, considerată o toxină uremică din cauza faptului că este un compus guanidinic, un rest provenit din metabolismul proteinelor. Ea se acumulează pe măsură ce funcția renală se degradează, iar din cauza faptului că inhibă sintaza oxidului nitric are capacitatea de a influența negativ sistemul cardiovascular, osos, dar și pe cel imun (4).

\section{SINTEZA DE NOVO A DIMETILARGININEI ASIMETRICE}

DMAA ia naștere prin procesul de proteoliză a resturilor metilate de L-arginină sub acțiunea protein-arginin-metil-transferazei 1. Metabolismul DMAA este însă controlat în mare parte de enzima dimetilarginin-dimetilaminohidrolază. Prin intermediul acestei enzime, dimetilarginina asimetrică este metabolizată în L-citrulină și dimetilamină. După ce are loc procesul de degradare proteolitică a proteinelor intracelulare metilate la nivelul citoplasmei celulare, acestea sunt eliberate extracelular, contribuind astfel la nivelurile interstițiale și plasmatice crescute de DMAA, care sunt controlate în continuare prin turnover-ul de proteine, $\mathrm{cu}$ generare de metilarginine (5). Studiile efectuate pe cohorte au creionat impactul puternic pe care îl are o creștere plasmatică ușoară a dimetilargininei asimetrice, fiind îndeajuns pentru a inhiba sinteza oxidului nitric, exacerbând astfel evenimentele cardiovasculare (6). Prin creșterea acestei metilarginine, se dezechilibrează astfel balanța dintre factorii cu protecție cardiovasculară și procesul de ateromatoză.

Studiile clinice efectuate în laborator pe animale și asupra subiecților umani au creionat prezența plasmatică a dimetilargininei asimetrice în condițiile în care clinic nu a fost manifestată boala vasculară. DMAA are o fereastră foarte restrânsă a concentrației plasmatice la subiecții sănătoși, între 0,22 și 0,69 $\mu \mathrm{mol} / \mathrm{I}$ (7). La cel mai mic dezechilibru plasmatic al acesteia, ea se asociază cu un risc cardiovascular înalt, trăsătură ce o diferențiază de ceilalți factori de risc convenționali. Multiple studii clinice prospective suplimentare se desfășoară în prezent în diverse populații de pacienți, printre care pacienți cu insuficiență cardiacă congestivă, pacienți cu transplant cardiac și pacienți cu hipertensiune pulmonară. În concluzie, un număr tot 
mai mare de studii clinice prospective au arătat că asocierea dintre nivelurile ridicate ale acestei metilproteine, evenimentele cardiovasculare majore și mortalitatea totală este mare și se extinde la diverse grupuri de pacienți.

\section{IMPLICAREA DIMETILARGININEI ASIMETRICE ÎN PATOLOGIA CARDIOVASCULARĂ}

După ce a fost evidențiată creșterea concentrației plasmatice a DMAA în cazul pacienților cu boală cronică renală, cercetătorii au început să studieze implicarea dimetilargininei asimetrice în cadrul altor patologii, care prezintă risc cardiovascular înalt. Astfel, s-a creionat rolul acesteia în cazul aterosclerozei (8), hipercolesterolemiei, hipertensiunii arteriale, diabetului zaharat, hiperhomocisteinemiei, preeclampsiei. Expunerea la acești factori de risc cardiovasculari are ca rezultat scăderea biodisponibilității oxidului nitric care ia naștere din endoteliu; secundar acesteia, este alterată bariera dintre factorii vasoconstrictori și vasodilatatori ai endoteliului. DMAA joacă un rol cheie în disfuncția endotelială, ateroscleroză, boala de artere coronare, accidente vasculare cerebrale, boala arterială periferică, iar un aspect caracteristic al acesteia este asocierea directă a prezenței plasmatice crescute de DMAA cu grosimea intimă-medie a arterei carotide (9).

\section{CONEXIUNEA DINTRE DIMETILARGININA ASIMETRICĂ ŞI FUNCȚIA RENALĂ}

Pacienții cu boală renală cronică prezintă un risc cardiovascular mult mai crescut față de restul populației, care nu este explicat pe deplin prin prezența factorilor de risc cunoscuți până în prezent. La nivelul rinichilor se găsește cea mai mare concentrație de dimetilarginin dimetilaminohidrolaza (DDAH) I, enzimă care se ocupă de eliminarea dimetilargininei asimetrice din organism.

Prin intermediul DDAH I, are loc metabolizarea DMAA în proporție de $80 \%$, asigurând o concentrație optimă a acestei metilproteine în vivo. 0 parte este transformată în citrulină și restul este eliminat renal. Activitatea enzimatică a DDAH I este inhibată în mod deosebit de stresul oxidativ care apare în diferite patologii, precum diabetul zaharat, hipercolesterolemia, hiperhomocisteinemia etc. Studiile efectuate au descoperit concentrații plasmatice mult crescute de dimetilarginină asimetrică la pacienții cu patologie renală, fiind considerat cel mai potent factor de risc cardiovas- cular descoperit până în prezent (10).

\section{DIMETILARGININA ASIMETRICĂ - O POSIBILĂ ABORDARE TERAPEUTICĂ PENTRU ATEROSCLEROZĂ}

O posibilă opțiune terapeutică pentru inversarea și controlarea procesului de ateroscleroză ar fi menținerea concentrației plasmatice de dimetilarginină asimetrică în limitele fiziologice, iar un mod prin care s-ar putea controla aceasta ar fi prin reechilibrarea balanței dintre nivelul seric al acestei metilproteine și sinteza constantă a oxidului nitric, acest lucru fiind posibil prin introducerea L-argininei în dieta subiecților cu patologii cardiovasculare asociate. Prin administrarea L-argininei, se reechilibrează producția de oxid nitric la nivel vascular și se îmbunătățește vasodilatația dependentă de endoteliu. Un aspect remarcabil conturat în urma studiilor efectuate a fost descoperirea DMAA ca fiind cel mai puternic inhibitor endogen al NO. Cu acest reper se face un pas important în înțelegerea procesului de ateroscleroză aflată în stadiul incipient. S-a conturat valoarea prognostică a dimetilargininei asimetrice în cadrul patologiilor cardiovasculare, renale, dar și în cazul bolnavilor în stare critică. De aceea, ar trebui efectuate multiple studii pentru a defini exact categoria de pacienți care este influențață cel mai mult de prezența acestei metilproteine (11).

În momentul de față, se desfășoară un studiu prospectiv în cadrul Spitalului Clinic Județean de Urgență Arad, în care se urmărește concentrația plasmatică a dimetilargininei asimetrice la pacienții cu afecțiuni cardiovasculare, corelând-o cu ceilalți factori de risc și cu patologiile asociate. Ceea ce ne interesează să conturăm din acest studiu este valoarea diagnostică a DMAA, posibilitatea utilizării ca metodă de screening la pacienții cardiaci și o posibilă utilizare curentă a acesteia în practica clinică.

\section{CONCLUZII}

Dimetilarginina asimetrică, o proteină metilată, este un nou factor de prognostic negativ al afecțiunilor cardiovasculare, iar importanța acesteia a început să apară în ultimii ani, când studiile efectuate pe pacienții cu insuficiență renală au conturat o mortalitate crescută din cauza complicațiilor cardiovasculare apărute la acești pacienți.

Din studiile recente, s-a conturat valoarea prognostică a dimetilargininei asimetrice în cadrul patologiilor cardiovasculare, renale, dar și în cazul bolnavilor în stare critică, deschizând calea de cercetare pentru studiile viitoare. 


\section{BIBLIOGRAFIE}

1. Fadi G Hage, Sulaf J Mansur, Dongqi Xing et al. Hypertension in women. Kidney International Supplements 2013 December;3(4):352-356.

2. Jan T. Kielstein, Danilo Fliser, Hendrik Veldink. Progress in uremic toxin research: Asymmetric Dimethylarginine and Symmetric Dimethylarginine: Axis of Evil or Useful Alliance? Seminars in dialysis 2009 Jul-Aug;22(4):436-450.

3. Patrick Vallance, James Leiper. Asymmetric Dimethylarginine and Kidney Disease Marker or Mediator? Journal of the American Society of Nephrology 2005 August;16(8):2254-2256.

4. C Murr, A Meinitzer, T Grammer et al. Association between Asymmetric Dimethylarginine and Neopterin in Patients with and without Angiographic Coronary Artery Disease. Scandinavian Journal of Immunology 2009 July;70(1): 63-67.

5. Arslan Arinc Kayacelebi, Jennifer Langen, Katharina Weigt-Usinger et al. Biosynthesis of homoarginine ( $\mathrm{hArg}$ ) and asymmetric dimethylarginine (ADMA) from acutely and chronically administered free $L$-arginine in humans. Amino acids 2015

September;47(9):1893-1908.

6. Rainer H. Böger, Asymmetric Dimethylarginine, an Endogenous Inhibitor of Nitric Oxide Synthase, Explains the "L-Arginine Paradox" and Acts as a Novel Cardiovascular Risk Factor, The Journal of Nutrition (Germany). 2004 October; 134(10):2842S-2847.

7. Tanya I Deneva-Koycheva, Lyudmila G Vladimirova-Kitova, Evgeniya A Angelova et al. Plasma asymmetric dimethylarginine levels in healthy people. Folia Medica 2011 Jan-Mar;53(1):28-33.

8. Maurício Batista Paes Landim, Antônio Casella Filho, Antônio Carlos Palandri Chagas. Asymmetric Dimethylarginine (ADMA) and Endothelial Dysfunction: Implications for Atherogenesis. Clinics (Sao Paolo). 2009 May; 64(5):471-478.
9. Kumiko Furuki, Hisashi Adachi, Mika Enomoto et al. Plasma Level of Asymmetric Dimethylarginine (ADMA) as a Predictor of Carotid Intima-Media Thickness Progression: Six-Year Prospective Study Using Carotid Ultrasonography. Hypertension Research 2008 June;31(6):1185-1189.

10. Manuela Di Franco, Bruno Lucchino, Fabrizio Conti et al. Asymmetric dimethyl arginine as a biomarker of atherosclerosis in rheumatoid arthritis. Mediators of Inflammation 2018 January;2018(1):1-13.

11. Mortensen KM, Itenov TS, Hansen MB et al. Mortality in critical illness: The impact of asymmetric dimethylarginine on survival - A systematic review and meta-analysis. Acta Anaesthesiologica Scandinavica 2019 March;63(6):708-719.

Conflict of interest: none declared Financial support: none declared 